\title{
Territorial Autonomy in the Shadow of Conflict: Too Little, Too Late?
}

\section{LARS-ERIK CEDERMAN ETH Zürich}

SIMON HUG Université de Genève

ANDREAS SCHÄDEL ETH Zürich

\section{JULIAN WUCHERPFENNIG University College London and ETH Zürich}

\begin{abstract}
$T$
This article evaluates the effect of territorial autonomy on the outbreak of internal conflict by analyzing ethnic groups around the world since WWII. Shedding new light on an ongoing debate, we argue that the critics have overstated the case against autonomy policies. Our evidence indicates that decentralization has a significant conflict-preventing effect where there is no prior conflict history. In postconflict settings, however, granting autonomy can still be helpful in combination with central power sharing arrangements. Yet, on its own, postconflict autonomy concessions may be too little, too late. Accounting for endogeneity, we also instrument for autonomy in postcolonial states by exploiting that French, as opposed to British, colonial rule rarely relied on decentralized governance. This identification strategy suggests that naïve analysis tends to underestimate the pacifying influence of decentralization.
\end{abstract}

$\mathbf{T}$ he turbulent and partly violent breakup of Yugoslavia and the Soviet Union in the early 1990s gave decentralization along ethnic lines a bad name. According to some scholars, offering ethnic groups regional autonomy triggers secessionist conflict. In particular, this view rejects ethnic federalism as a method of conflict resolution (e.g., Brubaker 1996; Bunce 1999; Bunce and Watts 2005; Cornell 2002; Snyder 2000). Other scholars, who typically focus on a wider set of cases, are much more optimistic about the stabilizing effect of decentralization. In their view, such arrangements do not merely function as grievancereducing concessions, but also as effective modes of governance in ethnically divided societies (e.g., Gurr 2000a; Hechter 2000; Lijphart 1985).

Is autonomy as perilous as its critics have claimed? To find out, we present an empirical evaluation of regional autonomy's effect on internal conflict. We argue that the skeptics have overstated the case against autonomy policies for at least four reasons. First, much of the previous research has covered select cases, making

Lars-Erik Cederman is Professor of International Conflict Research at ETH Zürich, Haldeneggsteig 4, 8092 Zürich, Switzerland (lcederman@ethz.ch).

Simon Hug is Professor at Département de science politique, Faculté des sciences économiques et sociales, Université de Genève, $40 \mathrm{Bd}$ du Pont d'Arve, 1211 Genève 4, Switzerland (simon.hug@unige.ch).

Andreas Schädel is Lecturer in International Security at ETH Zürich, Haldeneggsteig 4, 8092 Zürich, Switzerland (schaedel@icr.gess.ethz.ch).

Julian Wucherpfennig, University College London, 29/31 Tavistock Square, London, WC1H 9QU, United Kingdom (j.wucherpfennig@ucl.ac.uk).

We thank the editors of the APSR, the anonymous referees, Kristin Bakke, Manus Midlarsky, Brendan O'Leary, and Nicholas Sambanis for helpful comments and discussions, as well as audiences at presentations given at meetings of the American Political Science Association, Chicago, and the European Network for Conflict Research, University Essex. Members of the International Conflict Research group at ETH Zürich, including Nils-Christian Bormann, Micha Germann, Luc Girardin, Philipp Hunziker, Seraina Rüegger and Manuel Vogt also offered comments and crucial research support. This research was funded through the Swiss National Science Foundation (Grant No. 143213). it difficult, if not impossible, to set up fair comparisons. In particular, researchers typically highlight cases that have already experienced conflict, while ignoring peaceful ones. For instance, this focus characterizes research that analyzes autonomy concession as part of formal peace agreements. Second, previous studies have typically evaluated outcomes at the country level, thereby obscuring important differences within the countries under scrutiny. Third, when within-country variation in terms of decentralization has been considered, it has usually been studied in isolation from power sharing at the central level. Yet, such an approach cannot capture crucial stabilizing synergies between ethnic representation at both levels. Finally, scholars have often failed to pay attention to the problem of reverse causation. If governments offer autonomy to ethnic groups as a way to reduce or prevent anticipated violence, the previous literature may have underestimated its pacifying effect.

Avoiding over-aggregation and selection problems, this article uses a global, disaggregated dataset of politically relevant ethnic groups from 1946 to 2009. These new data on both territorial and governmental power sharing introduce a more objective baseline for comparison. Our focus lies on the potential for conflict prevention and peace building. We argue that the conflict-dampening effect of inclusive institutions can be expected to hinge on a history of conflict. We find that both regional autonomy and central power sharing within the national executive have a significant conflict-preventing impact before the onset of the first conflict. However, the situation is much less clear-cut once violence has occurred. While regional autonomy on its own may be "too little, too late" when it comes to preventing conflict recurrence, it is more effective if the group is also included in central power sharing arrangements.

Furthermore, our analysis explicitly addresses the endogenous nature of autonomy by exploiting systematic differences between groups in countries with French and British colonial legacies, thereby isolating its exogenous effect on postcolonial conflict. Our instrumental variable approach indicates that, if 
anything, the conflict-dampening effect of autonomy is most likely stronger once one considers the fact that such arrangements are more likely in cases that are prone to conflict to begin with.

\section{LITERATURE REVIEW}

In this article, we use the term "power sharing" to designate any scheme of governance that allows group representatives to engage in shared decision making, either through accommodation within the central executive (which we label governmental power sharing), or by granting certain territorially concentrated groups regional autonomy (which we refer to as territorial power sharing). The governmental type of power sharing overlaps with Lijphart's $(1969,1975)$ notion of consociationalism, although our definition is more restrictive in that it captures only ethnic relations while excluding dimensions other than executive power. A variety of dimensions have been stressed in the postconflict literature, such as peace agreements featuring economic, legislative, or military power sharing (cf. Hartzell and Hoddie 2003; Martin 2013; Mattes and Savun 2009). ${ }^{1}$ At the same time, our approach is more comprehensive than the conflict resolution literature since it includes power-sharing arrangements beyond formal peace agreements as well as situations that have not turned violent.

Given the group perspective adopted in this article, territorial power sharing implies that an ethnic group enjoys autonomy in at least one region predominantly settled by itself. Such autonomy includes federal arrangements that are based on territorial units conferring regional autonomy to specific ethnic groups, which are then often described as ethnofederal (see Christin and Hug 2012; Grigoryan 2012; McGarry and O'Leary 2009). However, other federal arrangements are only partially ethnic or explicitly nonethnic, as illustrated by the United States.

Autonomy has been subject to intensive study, but it remains unclear whether territorial decentralization actually reduces conflict. Several scholars claim that granting regions autonomy eases ethnic tensions and reduces the likelihood of conflict. Much of this argumentation builds directly or indirectly on Tiebout's (1957) classical model, which shows that decentralized provision of public goods can be an efficient way to resolve conflict in the presence of preference heterogeneity (see also Sambanis and Milanovic 2014). Beyond efficiency, decentralization reinforces democracy by bringing government closer to the people and increasing participation (e.g., Brancati 2006). In addition to improving the quality of governance, regional autonomy contributes directly to conflict reduction: "By making government more responsive to the concerns of disgruntled minorities, potentially secessionist groups

\footnotetext{
${ }^{1}$ While economic "horizontal" inequality at the group level can be expected to help trigger secessionist conflict (Bakke and Wibbels 2006; Cederman, Weidmann, and Gleditsch 2011; Langer and Stewart 2013) these additional aspects go beyond the scope of the present study (though see the Online Appendix for sensitivity analysis).
}

will be encouraged to feel confident of representation and protection for their most vital concerns" (Lustick, Miodownik, and Eidelson 2004, 210). In this context, representation implies both formal recognition of the secessionist group by integrating it within a legal framework of peaceful political coexistence (Bakke 2015; Bakke and Wibbels 2006) and its influence over policy outcomes (Hechter 2000). The territorial nature of such provisions contributes to satisfying the group's concern about guaranteeing its physical security as well as the survival of its ethnonationalist identity (Hannum 1996, 464). In this sense, protection helps mitigate the commitment problem that is endemic to stategovernment relations by making it harder for the state to renege on its promises (Jarstad and Nilsson 2008; Walter 2009).

Other scholars adopt a more skeptical perspective on regional autonomy, viewing it as an ineffective method of conflict resolution, or sometimes even as an impediment to peace (e.g., Brubaker 1996; Bunce 1999; Kymlicka 1998; Snyder 2000). According to Snyder (2000, 327), regional autonomy has a "terrible track record," as evidenced by the partly violent breakups of the Soviet Union (Hale 2008) and Yugoslavia in the early 1990s (Bunce 1999), as well as separatist violence in Russia, in the successor states of the Soviet Union (Bunce 1999; Cornell 2002). These observations have inspired criticism of decentralization along ethnic lines. Such arrangements, the critics argue, risk reinforcing divisive ethnic identities (Chapman and Roeder 2007) while "providing resources that groups can then use to bring more pressure on the state" (Elkins and Sides 2007, 693).

There is also little agreement in the literature that focuses specifically on autonomy concessions as a part of postconflict settlements. Many of these studies assert that negotiated civil war settlements featuring territorial autonomy provisions have a positive and significant effect on settlement stability (e.g., Hartzell, Hoddie, and Rothchild 2001; Hoddie and Hartzell 2005; Jarstad and Nilsson 2008; Martin 2013; Mattes and Savun 2009). Here, a key argument is that the offer of territorial decentralization constitutes a signal of moderate intent of the victor. Yet, many studies of decentralization in postconflict settings are much more skeptical. While agreeing that territorial decentralization in civil war settlements can be an effective solution for ethnically divided societies, Lake and Rothchild (2005) and Rothchild and Roeder (2005) assert that this is so only under very restrictive and unlikely conditions, such as robust democracy, moderate group leadership, mixed settlement patterns, and absence of ethnic dominance.

Pessimism about the pacifying postconflict effect of regional autonomy is especially strong in studies that argue in favor of partition as a solution to allegedly intractable conflict. Kaufmann (1996) insists that a stable settlement can only be achieved if the opposing groups are demographically separated into defensible enclaves. Arguing along similar lines, Chapman and Roeder (2007) also advocate partition as opposed to power sharing and autonomy. 
As is the case with the autonomy literature, studies of governmental power-sharing institutions adopt a wide spectrum of perspectives. Although such arrangements may facilitate the transition from civil conflict in the short run, the critics contend that they are likely to thwart the consolidation of peace and democracy in the long term by cementing ethnic divisions, undermining crosscutting cleavages, and increasing the likelihood of conflict escalation. Horowitz's (1985) classical study instead proposes institutions that provide politicians with incentives to reach out across ethnic boundaries (see also Roeder and Rothchild 2005).

There are some overlaps between this comparative literature and conflict studies that focus on the effect of decentralization, but the conclusions vary widely. Some authors endorse power sharing as a conflict resolution approach while remaining more skeptical about the effect of autonomy (Mattes and Savun 2009; Walter 2002, 2009). In contrast, Jarstad and Nilsson (2008) argue that autonomy curbs conflict more effectively than governmental power sharing (see also Martin 2013). ${ }^{2}$ Moreover, relatively few authors have considered the combined effect of territorial and governmental power sharing (though see Elkins and Sides 2007; McGarry and O'Leary 2009).

In sum, previous scholarship on power sharing and conflict suffers from several shortcomings that make it hard to assess the contribution of decentralization to conflict resolution. First, as we have argued, most of the relevant literature on autonomy and conflict does not distinguish between situations with and without a history of violent conflict. The focus is also generally on cases where conflict actually broke out while cases where autonomy had a preventive effect are overlooked. Second, conflict researchers rarely analyze the interaction between regional autonomy and power sharing at the center. Finally, few studies take reverse causation into account, which is a point to which we will return below.

\section{THEORY}

While much of the recent civil war literature has cast doubts on grievance-based arguments (for an overview, see Blattman and Miguel 2010), we build on another stream of literature that shows how governments' maltreatment of minorities triggers ethnic rebellions (e.g., Gurr 1993, 2000b; Petersen 2002). This claim can be directly derived from basic principles of political legitimacy in the modern world, following the emergence of nationalism (Gellner 1983). Nationalism prescribes that alien rule cannot be tolerated, which occurs wherever ethnic groups are blocked from political influence (Cederman 2013). Along these lines, the recent empirical literature contends that groups that are excluded from central executive power are more

\footnotetext{
2 These findings concern effects of types of power sharing adopted in peace agreements. Unlike the present study, they therefore cannot assess the conflict preventing effect of such arrangements in prewar settings, nor do these country-level studies tell us about the effect on specific groups.
}

likely to fight the government (see, e.g., Cederman and Girardin 2007; Cederman, Gleditsch, and Buhaug 2013; Cederman, Wimmer, and Min 2010). In short, "the less self-governance a nation has in a multinational state, the greater the possibility of ethnonationalist conflict" (Hechter 2004, 289).

These principles imply that full inclusion through central power sharing within the state's executive organs should be the safest way to reduce territorial conflict. In addition, because regional autonomy offers more executive influence than complete exclusion, such arrangements should also pacify the relations between governments and separatist groups, but to a lesser degree than governmental power sharing (Cederman, Gleditsch, and Buhaug 2013; Cederman, Wimmer, and Min 2010). We summarize this "power proximity" logic in three hypotheses that serve as the starting point of our empirical analysis:

H1. Included groups are less likely to rebel than groups that are fully excluded from executive power.

H2. Autonomous groups without central power access are less likely to rebel than groups that are fully excluded from executive power.

H3. Included groups are less likely to rebel than autonomous groups without central power access.

Once an armed conflict erupts, however, it drastically changes the relationship between the group and the incumbent government. Recent research along these lines controls for previous conflict, but does not go as far as analyzing how this modifies the impact of ethnic groups' power access (see, e.g., Cederman, Gleditsch, and Buhaug 2013; Cederman, Wimmer, and Min 2010; Sambanis and Zinn 2006).

Before considering the interaction between conflict history and power access, it is necessary to study the effect of past conflict separately. In principle, protracted violence could make both sides of a conflict less prone to resort to arms again. ${ }^{3}$ However, the empirical record suggests that recurrent conflict is much more likely than first onsets, leading Collier and Sambanis $(2002,5)$ to label this the "conflict trap" (see also Elbadawi, Hegre, and Milante 2008; Quinn, Mason, and Gurses 2007; Walter 2004).

With respect to ethnic conflict, the results point in the same direction. For example, Cederman, Wimmer, and Min (2010) find that ethnic groups' likelihood of experiencing recurrent conflict increases with the number of past onsets (see also Cederman, Gleditsch, and Buhaug 2013). Building on their arguments, we identify three sets of mechanisms that connect such a conflict history with outbreaks of recurrent fighting:

First, as regards attitudes to violence, armed conflict ceases to be unthinkable and becomes part of the repertoire of protest actions that the opposition can

\footnotetext{
${ }^{3}$ War wariness can lead ex-combatants to "forgive and forget," as Samii (2013) shows for the case of Burundi. Yet, in Burundi, learning occurred after two relapses of fighting.
} 
resort to. Such a breach of trust can be very hard to recover from, especially after long and bitter fighting. Social psychologists offer convincing explanations of the mechanisms that lead to intractable conflicts, including collective memory of past fighting, an "ethos" of conflict, and collective emotional orientations (Bar-Tal 2013). Likewise, Kalyvas (2006) shows that vengeance is a recurrent motivation of participation in civil wars. Clearly, without an active will to organize reconciliation and confidence building, memories of such events can live on for decades (Rydgren 2007). Failure to break the cycle of resentment risks transforming groupgovernment relations into hatred that could flare up quite easily (Bar-Tal 2013; Petersen 2002).

Second, with respect to the internal organization of the conflict parties, past conflict also tends to radicalize both sides. Radicalization typically leads to a splintering of the fronts, with hardliners insisting on fighting rather than accepting compromises (see, e.g., Asal, Brown, and Dalton 2012). Such a pattern includes attempts to outbid more moderate politicians with uncompromising and extremist positions (Horowitz 1985; Rabushka and Shepsle 1972). Fragmentation will lead to a lack of control on both sides, giving spoilers more room to block the implementation of peace initiatives, as Cunningham (2011) convincingly shows for the case of self-determination movements.

Third, in terms of fighting capacity, armed combat leaves behind not only mental scars but also typically an infrastructural legacy conducive to renewed conflict. In particular, failed or partial disarmament leaves both former rebels and governmental militias with recruitment networks, weapons, bases, and resources, on the basis of which new campaigns can be launched (Walter 2009; Wood 2008). In particular, this applies to the availability of small arms, which present a "continuous risk" (Fleshman 2001).

In short, uncurbed vengefulness and lingering radicalization, together with an opportunity structure conducive to violence, are a potent cocktail for recurrent conflict. For these reasons, we postulate the following:

H4. Ethnic groups that have experienced conflict in the past are more likely to experience further conflict onsets than those that have not.

We are now ready to explore how past conflict influences the pacifying effect of governmental concessions, as stated by $\mathrm{H} 1-\mathrm{H} 3$. Focusing on each of the three aforementioned mechanisms in turn, our analysis considers how prior conflict modifies the pacifying impact of both regional autonomy and full inclusion:

Postconflict concessions in a climate of hatred and vengefulness. Granting excluded groups regional autonomy may be helpful because it allows group leaders to argue for peaceful change within the system. In a postconflict situation such concessions may also send a costly signal of governmental moderation (Lake and Rothchild 2005, 123). Yet, autonomy concessions are less effective than central power sharing as pacifying tools in a climate of suspicion. Executive-level power sharing among the conflict parties creates a bargain- ing framework that gives them a stake in the cohesion of the state: "By this means, ethnonationalist leaders will be transformed from peripheral magnates anxious to drain power from the state into stakeholders committed to upholding it" (Hechter 2004, 288). Moreover, such a consociational setup makes is easier to restore interethnic trust and to reduce uncertainty for all parties: "By promoting an iterated exchange process, power-sharing institutions can prove reassuring, laying the basis for an ongoing relationship" (Rothchild 2008, 150).

Autonomy by itself in a postconflict context, however, is likely to be afflicted by two types of problems known from the literature on federalism (Bednar 2008, 68 ). In the absence of safeguards, the central government may encroach on the authority of the regionally based group, and, conversely, the region could fail to fulfill its obligations. Several scholars highlight that the latter problem may lead to the "ethnic capture" of regional institutions, and thus to secessionist tendencies (e.g., Roeder 2007). Building on Riker (1964), Filippov, Ordeshook, and Shvetsova (2004) emphasize that one way of avoiding such transgressions from tearing a federation apart is to ensure that politicians have stakes both at the regional and central levels, for instance through political parties. As these problems are more prevalent in a postwar setting, such safeguards linked to regional autonomy operate less effectively, as illustrated by the Naga and Manipuri insurgencies in India, the Moro secessionist conflict, or the patchy implementation of ethnic federalism in Ethiopia (Ghai 2000). Along similar lines, McGarry and O'Leary $(2005,15)$ argue that

federalism is about "shared-rule" as well as "self-rule," and the relevant constituent entities and peoples are likely to want a federal government that represents them, that is inclusive and, indeed, consociational. National minorities excluded from the federal government will be less inclined to promote their interests (see also Kymlicka 1998).

Whether federal or not, the central state needs to create incentives for potentially separatist politicians demonstrating that working within the system yields political advantages, both for their personal careers and for the groups that they claim to represent (see, e.g., Bednar 2008; Filippov, Ordeshook, and Shvetsova 2004; Riker 1964). Such incentives were introduced in postconflict Nigeria, where the victorious Gowon government followed what Bah $(2005,93)$ calls an "inclusionary approach" and "generous postwar reconciliation" that included general amnesty, reintegrated the secessionist Igbos in the civil service, and rehabilitated some of the destroyed areas. More than forty years after the end of the Biafran War, violence has still not recurred along the original conflict lines. Likewise, the successful inclusion of the Punjabi-Sikhs in the federal Indian government further illustrates the positive effects of combined regional autonomy and full inclusion after a conflict (Guha 2008).

For these reasons, we conclude that efforts to overcome the hostility of past conflict require a 
compromise at the level of central government rather than mere decentralization of authority within a regional framework.

Postconflict concessions and extremist splintering. We have argued that past conflict tends to produce organizational factions on both sides, some of which may refuse to give up the fight for full independence. Under such circumstances, it does not take much for one small extremist faction to sabotage attempts to reach compromise, as the peace process in the southern Philippines has shown. The 1996 Jakarta agreement granting meaningful autonomy to the Moro people was signed by the Moro National Liberation Front (MNLF) but its rejection by the more radical, independence-seeking Moro Islamic Liberation Front (MILF) resulted in continued armed insurgency (Bertrand 2000).

It is therefore essential that any settlement be as inclusive as possible. If offered not until the outbreak of violent conflict, autonomy concessions could be destabilizing by dividing the self-determination movement:

An early, generous offer of autonomy, made before extreme separatist organizations outflank moderate leaders, may avert secession. A similar offer, made after separatist violence has broken out, may well do what opponents of concessions fear: it may testify to the weaknesses or vacillation of the central government and the success of the separatist, thereby fortifying their will to fight on (Horowitz 1985, 625).

Failed negotiations with the center can produce frustrations that could be exploited by radical separatists (Bakke 2015,27). Furthermore, winning over the hearts and minds of extremists is very difficult if merely regional autonomy is on offer since this will be seen as "too little, too late" once the relationship between the group and the government has turned violent. Without credible commitments that the state will not renege on its autonomy promises (Lake and Rothchild 2005), why should extremists be satisfied with a consolation prize that does not even guarantee them decisive influence over the central state institutions, let alone full independence? Moreover, autonomous institutions can more easily be used for mobilization purposes by ethnic populists if they are detached from states' central decision-making mechanisms (Bunce 1999; Snyder 2000). Where ethnic and regional boundaries overlap, intense competition between regional parties may also facilitate ethnic outbidding because regional parties competing for the same electorate may adopt increasingly extreme views to attract votes away from other regional parties (Brancati 2006, 658). Relying on explicit evidence that organizational fragmentation fuels conflict, Cunningham (2011) argues that fragmented self-determination movements are more likely to respond violently to governmental concessions than are united ones (see also Bakke 2015, 27-29).

Of course, central power sharing can also break down because of extremist posturing following conflict. Nevertheless, governmental power sharing leaves less room for separatist activism and makes pragmatic politicians more successful. Thanks to their influence within the state's central executive, moderate group representatives not only have more of a personal stake in the future of their country, but are also more likely to claim ownership of national policies by showing that they can deliver favorable policy outcomes:

If the rebels are represented at different levels of government their enemies cannot decree or implement policies without their consent. Under these conditions, the rebels' enemies will be unable to pursue any policies, whether military, economic, cultural, or relating to autonomy and federalism, that are detrimental to the rebels. The sharing of decision-making power helps ensure that other kinds of power sharing are implemented and opens up the possibility for both groups to shape future policies (Mattes and Savun 2009, 742).

Thus, as long as the ethnic group remains excluded from national executive influence, there should be more room for confrontational and extremist agitation, especially if the central government subjects it to unfavorable policies. In contrast, central power sharing can be expected to have a more pervasive pacifying impact even in postconflict situations, precisely because it involves the former belligerents in central decision making: "The more integrated the rebel group is in the political system, the less incentives it will have to disrupt it" (Mattes and Savun 2009, 742). Evidence for this claim is provided by the successful integration of the former belligerent Igbo in Nigeria after the Biafran War (Bah 2005) or the coming into power of the Tigrayan People's Liberation Front (TPLF) after the ousting of Mengistu in Ethiopia (Young 2006).

Postconflict concessions and secessionist capacity building. Finally, we investigate whether territorial or power-sharing concessions influence secessionists' mobilization capacity. While far from all autonomy concessions create a government in waiting, devolution reforms set up decision making institutions and resources that can be exploited by secessionists to support renewed fighting if their increasingly radical demands are not satisfied. For example, in the northeastern region of India, separatists were rewarded with the creation of Nagaland and Manipur as full-fledged states of the Indian Union in 1963 and 1972 respectively. However, despite being granted substantial autonomy, armed groups in these states subsequently radicalized their demands and continued to fight as "some of the most sophisticated militant outfits in the region in terms of their access to weapons and funding, level of training, and network of safe areas" (Lacina 2009, 1014). As we have seen, several authors contend that regional autonomy along ethnic lines tends to empower separatist politicians:

Many institutions of partitioned decisionmaking, such as the powers of autonomous homelands in ethnofederal states, can be abused by regional leaders, including ethnomilitary warlords, to press the central government for further devolution and to extract income that can be invested in future fighting capacity (Rothchild and Roeder 2005, 37). 
In contrast, governmental power sharing increases the need to bargain and coordinate policies on a daily basis as opposed to creating a separate compartment of governance. This in turn increases transparency in interactions between the government and former rebels, thus making it harder for either side to rebuild preemptive military capability (Hartzell and Hoddie 2003). Following the Tuareg rebellion in the 1990s in Mali, high-ranking rebel officers were appointed to leadership positions in the army and were also assigned to key nonmilitary government positions. Transparency and coordination were also increased by the peace processes in El Salvador, Mozambique, and Djibouti, where former rebel armies were integrated into the national armed forces and participated in the nonviolent political process (Glassmyer and Sambanis 2008). After civil wars, security guarantees through powersharing arrangements are not sought merely by the former rebels, but also by the incumbents to state power:

Former combatants require assurances that no single group will be able to use the power of the state to secure what they failed to win on the battlefield, and perhaps threaten the very survival of rivals. Institutional choice in this environment is driven by the need to protect the interests of all signatories to the agreement. Power sharing serves as the mechanism that offers this protection by guaranteeing all groups a share of state power (Hartzell and Hoddie 2003, 319).

Furthermore, in most cases, rebel fighting capacity depends critically on mobilization. As we have argued above, far-reaching concessions granting previously excluded groups influence at the center can also be expected to make separatist recruitment efforts more difficult. In this sense, grievance reduction should decrease mobilization capacity (Cederman, Gleditsch, and Buhaug 2013, Chap. 3).

Our discussion of the three mechanisms suggests that governmental and territorial power-sharing arrangements will have different effects depending on whether they are introduced preventively before or reactively after a conflict. Based on these insights, we can therefore reformulate our expectations concerning prior conflict and concessions by breaking up hypotheses $\mathrm{H} 1-\mathrm{H} 3$ depending on whether or not conflict has already occurred between the group and the government. We start by covering the preconflict case:

H1a. Before the outbreak of the first conflict, included groups are less likely to rebel than groups that are fully excluded from executive power.

H2a. Before the outbreak of the first conflict, autonomous groups without central power access are less likely to rebel than groups that are fully excluded from executive power.

H3a. Before the outbreak of the first conflict, included groups are less likely to rebel than autonomous groups without central power access.

The next set of hypotheses applies to relationships that have already turned violent:
H1b. After the outbreak of the first conflict, included groups are less likely to rebel than groups that are fully excluded from executive power.

$\mathrm{H} 2 \mathrm{~b}$. After the outbreak of the first conflict, autonomous groups without central power access are less likely to rebel than groups that are fully excluded from executive power.

H3b. After the outbreak of the first conflict, included groups are less likely to rebel than autonomous groups without central power access.

Once the group-state relationship turns violent, our theory tells us that $\mathrm{H} 1 \mathrm{~b}$ and $\mathrm{H} 3 \mathrm{~b}$ should find support. Because our analysis implies that autonomy without central power access loses much of its effect in a postconflict setting, H2b is very much in doubt. In other words, after conflict, governmental power sharing is the only mode of ethnic inclusion that robustly prevents renewed violence. In essence, on its own, regional autonomy is likely to be "too little, too late" once violent conflict has erupted.

Given the power proximity logic, we have so far assumed that groups can enjoy either governmental or territorial powersharing. However, as noted in the introduction, it is perfectly possible for regional autonomy to coexist with power sharing at the central level, as illustrated by Yugoslav and Indian federalism, as well as current power-sharing arrangements in Bosnia and Herzegovina, Ethiopia, and Nigeria. This distinction allows us to formulate a more refined hypothesis as regards the effectiveness of postwar autonomy and inclusion combined:

H5b. After the outbreak of the first conflict, autonomous groups with central power access are less likely to rebel than groups that are fully excluded from executive power.

H6b. After the outbreak of the first conflict, autonomous groups with central power access are less likely to rebel than groups that are autonomous but without access to central power.

So far we have analyzed how ethnic representation at the regional and central levels influences the prospects of peace. Going beyond this relatively static perspective, we derive a hypothesis that focuses on changes in the provision of autonomy. Previous research on ethnic conflict suggests that conflict becomes much more likely if the group in question loses its current power status. Such downgrading is known to trigger violent reactions in the immediate period after the reversal (Petersen 2002). Within a broad macrohistorical context, Hechter (2000) associates nationalist mobilization in general, and peripheral nationalism in particular, with the shift from indirect to direct rule. With respect to political violence, Cederman, Wimmer, and Min (2010) and Cederman, Gleditsch, and Buhaug (2013, Chap. 4) find strong evidence that civil war onsets are considerably more likely during a two-year period following a status loss. More specifically relating to regional autonomy, McGarry and O'Leary (2009, 11) argue that conflict is likely to follow if governments 


\section{TABLE 1. Power Status of EPR-ETH Groups}

\begin{tabular}{lcc}
\hline Power Access & Group Years & Territorial Onsets \\
\hline Included & 7,926 & 13 \\
Included with autonomy & 1,635 & 10 \\
Included without autonomy & 6,291 & 3 \\
Excluded with autonomy & 5,073 & 23 \\
Excluded without autonomy & 10,490 & 100 \\
Total & 23,525 & 136 \\
\hline
\end{tabular}

attempt to revoke already granted autonomous rights: "To an important extent, secession and violence in the territory of many failed federations followed directly from attempts by certain groups to centralize these federations." They conclude that violence is not so much caused by decentralization as by its opposite, centralization. Prominent examples of retraction and failure of autonomy arrangements that contributed to fueling conflict include the Kurds in Iraq and the Southern groups in the Sudan (O'Leary 2012), Punjab and Kashmir in India (Singh 1993), Eritreans in Ethiopia (Negash 1997) as well as the Kosovars in Yugoslavia, where Milosevic's efforts to recentralize Yugoslavia also revoked the autonomous status of Kosovo in 1990 (Gagnon 2004). Grievances over this downgrading turned into open conflict a few years later.

Drawing on new data on territorial claims and concessions, Sambanis and Zinn (2006) find that the imposition of direct rule through the revocation of autonomous rights increases the risk of secessionist conflict. This reasoning can be formalized in the following way:

H7. Groups that have recently had their autonomous status revoked are more likely to rebel than those that have not experienced such status loss.

Having stated our theoretical claims, we now turn to the empirical evidence needed to evaluate their validity.

\section{DATA}

We test our hypotheses by using group-level data on ethnic groups' access to executive power. The necessary information is provided by the most recent version of the Ethnic Power Relations dataset (EPR-ETH), covering politically relevant ethnic groups worldwide from 1946 through 2009. ${ }^{4}$ Political relevance applies to those groups that are active in national politics and/or directly discriminated against by the government.

\footnotetext{
${ }^{4}$ The Online Appendix provides more information about the dataset. The data can be found at http://www.icr.ethz.ch/data/ growup/epr-eth. See Cederman, Wimmer, and Min (2010) for the original version of EPR. It should be noted that the Minorities at Risk (MAR) dataset (Gurr 1993) does not include all majority groups and is therefore less suitable for the purposes of this article (Hug 2013).
}

The EPR-ETH dataset is especially suitable for our analytical purposes because it offers a series of poweraccess categories that include theoretically relevant types of power sharing. The power access variable is divided into three main groups based on whether the group in question (1) rules alone, (2) shares power, or (3) is excluded from executive power. The groups that rule alone cannot fight the state by definition and are therefore dropped from the empirical analysis (Cederman, Wimmer, and Min 2010). The second set of power configurations corresponds to central power-sharing arrangements, whether of formal or informal nature. Included groups that share power enjoy meaningful representation within the country's executive. The third main class of power configurations features groups that have no regular representation within the executive, and can therefore be labeled as excluded.

In the subsequent analysis, we operationalize governmental power sharing at the center as power sharing in either a junior or a senior role, with a view of testing $\mathrm{H} 1$ and H3 both (a) before and (b) after the first conflict. Furthermore, we identify territorial power sharing by ethnic groups with the corresponding EPR-ETH subcategory for regional autonomy. By "regional" we refer to a substate unit below the level of the state as a whole, such as provinces and federal administrative units above the level of local counties.

Previous versions of the dataset restricted the coding of regional autonomy to excluded groups. For example, within the former Yugoslavia, the Vojvodina Hungarians enjoy regional autonomy of this type. We use this original coding that restricts autonomy to excluded groups to test $\mathrm{H} 2$ and $\mathrm{H} 3$ (a,b). However, H5b and $\mathrm{H} 6 \mathrm{~b}$ require a coding of autonomy that extends to included groups as well. Thus, we also introduce a novel coding of regional autonomy that allows for the combination with central inclusion. Table 1 contains a basic summary of our data, with the novel coding that distinguishes between included groups with and without autonomy given in italics.

Having discussed the main independent variables, we now turn our attention to the dependent variable, which denotes outbreak of territorial civil conflict based on a group-level coding of the Uppsala Conflict Data Program's Armed Conflict Dataset (ACD) (Gleditsch et al. 2002), with supplementary information from the Non-State Actors dataset (Cunningham, Gleditsch, and Salehyan 2009). Because our focus is on 


\section{TABLE 2. Overview of Hypotheses}

\begin{tabular}{|c|c|c|}
\hline Hypothesis & Expression & Model \\
\hline $\begin{array}{l}\mathrm{H} 1 \\
\mathrm{H} 2\end{array}$ & $\begin{array}{l}\beta_{\text {inclusion }}>\beta_{\text {exclusion }} \\
\beta_{\text {autonomy }}>\beta_{\text {exclusion }}\end{array}$ & $\begin{array}{l}1 \\
1\end{array}$ \\
\hline H3 & $\beta_{\text {inclusion }}<\beta_{\text {autonomy }}$ & 1 \\
\hline $\mathrm{H} 4$ & $\beta_{\text {postwar }}>0$ & 1 \\
\hline $\begin{array}{l}\mathrm{H} 1 \mathrm{a} \\
\mathrm{H} 2 \mathrm{a}\end{array}$ & $\begin{array}{l}\beta_{\text {inclusion }}>\beta_{\text {exclusion }} \text { if postwar }=0 \\
\beta_{\text {autonomy }}>\beta_{\text {exclusion }} \text { if postwar }=0\end{array}$ & $\begin{array}{l}2 \\
2\end{array}$ \\
\hline $\mathrm{H} 3 \mathrm{a}$ & $\beta_{\text {inclusion }}<\beta_{\text {autonomy }}$ if postwar $=0$ & 2 \\
\hline $\mathrm{H} 1 \mathrm{~b}$ & $\beta_{\text {inclusion }}>\beta_{\text {exclusion }}$ if postwar $=1$ & 2 \\
\hline $\mathrm{H} 2 \mathrm{~b}$ & $\beta_{\text {autonomy }}>\beta_{\text {exclusion if postwar }}=1$ & 2 \\
\hline $\mathrm{H} 3 \mathrm{~b}$ & $\beta_{\text {inclusion }}<\beta_{\text {autonomy }}$ if postwar $=1$ & 2 \\
\hline $\mathrm{H} 5 \mathrm{~b}$ & $\beta_{\text {autonomy } \& \text { inclusion }}<\beta_{\text {exclusion }}$ if postwar $=1$ & 3 \\
\hline $\mathrm{H} 6 \mathrm{~b}$ & $\beta_{\text {autonomy } \& \text { inclusion }}<\beta_{\text {autonomy }}$ if postwar $=1$ & 3 \\
\hline $\mathrm{H} 7$ & $\beta_{\text {downgraded from autonomy }}>0$ & 4 \\
\hline
\end{tabular}

regional autonomy concessions in separatist conflicts, we study territorial rather than governmental conflict, as defined by the ACD dataset. Specifically, our analysis is based on the ACD2EPR dataset, which maps each conflict onset to corresponding EPR group(s), provided that the rebel organization claimed to support the ethnic group and members of the group participated in combat (Wucherpfennig et al. 2012).

Based on this conflict coding, it is straightforward to capture a history of previous conflict with a dummy variable that equals 1 if the group experienced conflict with the government since 1946 or since the country became independent. ${ }^{5}$ This variable is crucial for the tests of all hypotheses that separate (a) prewar and (b) postwar cases through a multiplicative interaction term.

In keeping with previous research, we also control for group size (Cederman, Gleditsch, and Buhaug 2013; Cederman, Wimmer, and Min 2010). We expect an inverse U-shaped relationship since smaller groups should be less likely to trigger territorial conflict due to their limited resources. Yet, very large groups will be more inclined to try to topple the government in a governmental conflict. Thus, we enter relative group size as both linear and squared terms. ${ }^{6}$

Our analysis also controls for the ethnic structure of the state as a whole as well as for an important interaction effect applying to states with many ethnic groups. According to Walter's (2009) strategic logic, the number of excluded groups should be negatively related to the risk of conflict since governments facing many ethnic groups will be less willing to make concessions to single groups in order to deter consequent

\footnotetext{
5 There is a possibility that conflict before 1946 could have affected the relationship, but this is not part of the variable coding.

${ }^{6}$ Relative group size $g \in[0,1)$ comparing the population of the group $G$ to the population of the incumbent $I$ is defined as $\frac{G}{G+I}$ if the group is excluded and as $G / I$ if the group is included (since the rebelling group left the incumbent coalition and would otherwise be counted twice).
}

challenges or further demands by other groups, as illustrated by Moscow's hard line in dealing with the Chechens' claims.

In addition, we introduce a number of standard variables to control for various country-level properties:

- Federal institutions at the country level, as defined by Bednar (2008).

- Logged GDP per capita of the country as a whole, lagged (Penn World Table 7.0; see Heston, Summers, and Aten 2011).

- Logged population size of the country, lagged (Penn World Table 7.0; see Heston, Summers, and Aten 2011).

- Dummy variable for ongoing conflict based on the ACD2EPR conflict data indicating if there was an ongoing conflict involving any other group in the country during the preceding year.

- Number of years since the previous conflict, entered as a nonlinear function, based on natural cubic splines with three knots (see Beck, Katz, and Tucker 1998).

\section{ANALYSIS}

Our empirical analyses feature a series of group-level models. The sample encompasses all politically relevant EPR-ETH groups with a distinct settlement area from 1946 through 2009 (Wucherpfennig et al. 2011). ${ }^{7}$ Given our dependent variable of group-level conflict onset, we conducted all analyses using logit models with standard errors clustered by country. Ongoing conflict years were dropped from the analysis. Table 2 offers an overview of our hypotheses and the respective models from our empirical estimations given in Table 3. Because of the categorical nature of our key independent variable, as well as the conditional nature of some of

\footnotetext{
7 This amounts to 23,501 group years of which 136 coincide with onsets of territorial conflict. An additional 55 onsets were classified as governmental and thus not included in the main dependent variable.
} 
TABLE 3. Effect of Inclusion and Autonomy on Conflict Onset

\begin{tabular}{|c|c|c|c|c|c|}
\hline & Hypothesis & (1) & (2) & (3) & (4) \\
\hline Inclusion & $\mathrm{H} 1 / \mathrm{H} 1 \mathrm{a}$ & $\begin{array}{c}-1.835^{* * *} \\
(0.292)\end{array}$ & $\begin{array}{c}-1.944^{* * *} \\
(0.398)\end{array}$ & & \\
\hline Incl. \& autonomy & & & & $\begin{array}{r}-1.307^{*} \\
(0.555)\end{array}$ & $\begin{array}{r}-1.249^{*} \\
(0.551)\end{array}$ \\
\hline Incl. w/o autonomy & & & & $\begin{array}{c}-2.842^{* * *} \\
(0.754)\end{array}$ & $\begin{array}{c}-2.802^{* * *} \\
(0.754)\end{array}$ \\
\hline Autonomy & $\mathrm{H} 2 / \mathrm{H} 2 \mathrm{a}$ & $\begin{array}{c}-0.951^{* * *} \\
(0.285)\end{array}$ & $\begin{array}{c}-1.409^{* * *} \\
(0.203)\end{array}$ & $\begin{array}{c}-1.354^{* * *} \\
(0.202)\end{array}$ & $\begin{array}{c}-1.314^{* * *} \\
(0.200)\end{array}$ \\
\hline Postwar & $\mathrm{H} 4$ & $\begin{array}{l}1.161^{* * *} \\
(0.271)\end{array}$ & $\begin{array}{l}0.979^{* * *} \\
(0.294)\end{array}$ & $\begin{array}{l}1.007^{* * *} \\
(0.292)\end{array}$ & $\begin{array}{l}0.997^{* * *} \\
(0.297)\end{array}$ \\
\hline Inclusion $\times$ postwar & & & $\begin{array}{c}0.400 \\
(0.731)\end{array}$ & & \\
\hline Incl. \& aut. $\times$ postwar & & & & $\begin{array}{c}0.337 \\
(0.790)\end{array}$ & $\begin{array}{c}0.329 \\
(0.785)\end{array}$ \\
\hline Incl. w/o aut. $\times$ postwar & & & & $\begin{array}{c}0.468 \\
(1.363)\end{array}$ & $\begin{array}{c}0.466 \\
(1.361)\end{array}$ \\
\hline Autonomy $\times$ postwar & & & $\begin{array}{l}1.083^{* *} \\
(0.356)\end{array}$ & $\begin{array}{l}1.093^{* *} \\
(0.342)\end{array}$ & $\begin{array}{l}1.088^{* *} \\
(0.344)\end{array}$ \\
\hline Downgraded from autonomy & $\mathrm{H} 7$ & & & & $\begin{array}{l}1.835^{* *} \\
(0.662)\end{array}$ \\
\hline Other downgraded & & & & & $\begin{array}{c}0.529 \\
(0.488)\end{array}$ \\
\hline Relative group size & & $\begin{array}{c}0.570 \\
(1.929)\end{array}$ & $\begin{array}{c}0.579 \\
(1.975)\end{array}$ & $\begin{array}{c}0.542 \\
(1.946)\end{array}$ & $\begin{array}{c}0.344 \\
(1.957)\end{array}$ \\
\hline Relative group size ${ }^{2}$ & & $\begin{array}{c}-2.117 \\
(3.070)\end{array}$ & $\begin{array}{c}-2.135 \\
(3.144)\end{array}$ & $\begin{array}{c}-2.089 \\
(3.138)\end{array}$ & $\begin{array}{c}-1.848 \\
(3.127)\end{array}$ \\
\hline Number of excl. groups & & $\begin{array}{c}-0.024^{* * *} \\
(0.006)\end{array}$ & $\begin{array}{c}-0.020^{* * * *} \\
(0.006)\end{array}$ & $\begin{array}{c}-0.019^{* *} \\
(0.006)\end{array}$ & $\begin{array}{c}-0.019^{* *} \\
(0.006)\end{array}$ \\
\hline Federal & & $\begin{array}{l}0.816^{* *} \\
(0.296)\end{array}$ & $\begin{array}{l}0.844^{* *} \\
(0.313)\end{array}$ & $\begin{array}{c}0.795^{*} \\
(0.309)\end{array}$ & $\begin{array}{c}0.785^{*} \\
(0.318)\end{array}$ \\
\hline $\log g d p_{t-1}$ & & $\begin{array}{c}0.043 \\
(0.108)\end{array}$ & $\begin{array}{c}0.039 \\
(0.110)\end{array}$ & $\begin{array}{c}0.030 \\
(0.108)\end{array}$ & $\begin{array}{c}0.034 \\
(0.109)\end{array}$ \\
\hline Log population & & $\begin{array}{c}0.237^{* *} \\
(0.080)\end{array}$ & $\begin{array}{c}0.204^{*} \\
(0.088)\end{array}$ & $\begin{array}{c}0.177^{*} \\
(0.088)\end{array}$ & $\begin{array}{c}0.174^{+} \\
(0.089)\end{array}$ \\
\hline Ongoing conflict & & $\begin{array}{l}0.675^{* *} \\
(0.259)\end{array}$ & $\begin{array}{l}0.704^{* *} \\
(0.239)\end{array}$ & $\begin{array}{l}0.670^{* *} \\
(0.235)\end{array}$ & $\begin{array}{l}0.675^{* *} \\
(0.227)\end{array}$ \\
\hline Peace years & & $\begin{array}{c}-0.267^{* * *} \\
(0.064)\end{array}$ & $\begin{array}{c}-0.263^{* * *} \\
(0.063)\end{array}$ & $\begin{array}{c}-0.261^{* * *} \\
(0.063)\end{array}$ & $\begin{array}{c}-0.269^{* * *} \\
(0.061)\end{array}$ \\
\hline Constant & & $\begin{array}{c}-6.307^{* * *} \\
(1.337)\end{array}$ & $\begin{array}{c}-5.944^{* * *} \\
(1.388)\end{array}$ & $\begin{array}{c}-5.581^{* * * *} \\
(1.380)\end{array}$ & $\begin{array}{c}-5.562^{* * *} \\
(1.382)\end{array}$ \\
\hline Wald Test $\chi^{2}$ & & & & & \\
\hline$\beta$ (incl.) $=\beta$ (aut.) & H3/H3a & $4.70^{*}$ & 1.43 & & \\
\hline$\beta$ (incl. $)+\beta$ (incl. $\times$ p.w. $)=0$ & $\mathrm{H} 1 \mathrm{~b}$ & & $8.65^{* *}$ & & \\
\hline$\beta$ (aut.) $+\beta($ aut. $\times$ p.w. $)=0$ & $\mathrm{H} 2 \mathrm{~b}$ & & 0.96 & & \\
\hline $\begin{array}{l}\beta(\text { incl. })+\beta \text { (incl. } \times \text { p.w })= \\
\beta(\text { aut. })+\beta(\text { aut. } \times \text { p.w. })\end{array}$ & $\mathrm{H} 3 \mathrm{~b}$ & & $5.06^{*}$ & & \\
\hline$\beta$ (incl.\&aut.) $+\beta$ (incl.\&aut. $\times$ p.w. $)=0$ & $\mathrm{H} 5 \mathrm{~b}$ & & & $3.94^{*}$ & \\
\hline $\begin{array}{c}\beta(\text { incl.\&aut. })+\beta(\text { incl.\&aut. } \times \text { p.w. })= \\
\beta(\text { aut. })+\beta(\text { aut. } \times \text { p.w. })\end{array}$ & $\mathrm{H} 6 \mathrm{~b}$ & & & 2.01 & \\
\hline Observations & & 23,525 & 23,525 & 23,525 & 23,525 \\
\hline Log-Pseudolikelihood & & -690.534 & -688.269 & -685.359 & -682.237 \\
\hline
\end{tabular}

our hypotheses, we also use Wald tests to test for equality between coefficients (e.g., H3) and joint significance with interacted terms (e.g., H1b-3b).

Using excluded groups without autonomy as the baseline category, Model 1 clearly supports the power proximity principle as stated by hypotheses $\mathrm{H} 1-\mathrm{H} 3$.
Indeed, the conflict-reducing impact of full inclusion through central power sharing is especially strong, but regional autonomy also has a pacifying effect vis-àvis exclusion. Furthermore, there is a discernible difference between central power sharing and regional autonomy. Finally, in line with previous research, H4 
receives very strong support as well, suggesting that a history of conflict increases the risk of recurrent onsets.

Model 2 introduces the crucial differentiation between preconflict and postconflict settings. The estimates show that both governmental and territorial power sharing reduce the occurrence of conflict if offered before the outbreak of violence, although the difference between central power sharing and autonomy misses significance at conventional levels. On the whole, however, this preventive impact of both types of shared power supports $\mathrm{H} 1 \mathrm{a}-\mathrm{H} 3 \mathrm{a}$.

This picture changes in important ways once we shift attention to group-government relations after the outbreak of the first conflict. Because the marginal effects are now partly determined by the interaction terms, we rely on Wald tests at the bottom of the table. We find that inclusion still prevents recurrent conflict more effectively compared to full exclusion (H1b) or autonomous arrangements $(\mathrm{H} 3 \mathrm{~b})$. While postwar power sharing at the center is an effective means of stabilizing peace, our data suggest that in postwar situations the conflict-dampening effect of autonomous institutions cannot be statistically separated from that of full exclusion. This casts doubt on $\mathrm{H} 2 \mathrm{~b}$ in accordance with our theoretical expectations.

So far, the analysis has relied on a mutually exclusive coding of power access according to which inclusion overrides autonomy. This specification makes it impossible to evaluate the separate effect of autonomy for included groups. As noted above, we therefore extend the existing autonomy coding of EPR-ETH by newly coding whether the included groups that participate in central power sharing simultaneously enjoy autonomy. This refinement allows us to test $\mathrm{H} 5 \mathrm{~b}$, which states that regional autonomy is no longer an effective strategy for conflict prevention, unless it is combined with executive power sharing at the central level. The estimates reported in Model 3 support this hypothesis. Interacting both the variables pertaining to inclusion with or without autonomy with the postwar dummy variable shows that, whether autonomy is offered or not, inclusion retains its pacifying effect even in situations with a history of conflict. In contrast, the effectiveness of autonomy without inclusion is compromised once conflict has erupted between the group and the government. A test of H6b indicates that the difference between autonomy with inclusion and autonomy without inclusion misses conventional levels of statistical significance $(p=0.16){ }^{8}$

Our findings up to this point suggest that regional autonomy is probably not a robust mode of securing peace in situations which have seen a history of violent conflict, at least if regional autonomy is not com-

\footnotetext{
${ }^{8}$ In Model 3, the power proximity principle breaks down for prewar settings, at least to the extent that included groups without autonomy experience less conflict than those with autonomy. This may be partly due to the limited number of observations in each category once the included groups are divided into two subcategories. Most importantly, however, included groups that also enjoy autonomous status experience more conflict because they tend to be part of larger and ethnically more complex states. The next section will return to this issue of endogeneity.
}

bined with governmental power sharing at the central level. While this is entirely in line with our theoretical expectations, we have said nothing about substantial effects that should be expected for groups that could benefit from such provisions. To explore these important counterfactuals, we rely on "average predictive differences" proposed by Gelman and Hill (2007, 466). Instead of comparing predicted probabilities for some imagined case, by, for example, holding all variables at their mean, this method is based on calculating the predicted changes in probabilities for all relevant cases in the sample. Thus, we sampled 1,000 values from the estimated parameter distribution of Model 3 and computed the predicted probability of conflict in two scenarios for all group-years for which an upgrade to regional autonomy or inclusion was possible. The first scenario assumes that no such upgrade occurred, whereas the second one assumes that autonomy or either type of inclusion was granted. The differences in these probabilities were then averaged for each parameter set. The density of these "average predictive differences" are depicted in Figures 1 and 2 for the preconflict and postconflict situations respectively.

Focusing on preconflict settings, Figure 1 shows that both territorial and governmental power sharing reduce the probability of conflict onset, with the latter category divided into two subcategories. While inclusion without autonomy appears to be more effective than regional autonomy and inclusion with autonomy, the latter two also produce more peaceful outcomes than would be the case in their absence. Once we turn to the postconflict cases, however, it becomes clear that governmental power sharing continues to exert a powerful negative effect on the onset probability, whether it is combined with autonomy or not (see Figure 2). As is the case in preconflict settings, virtually all average changes in probability are within the negative range, thus clearly separated from zero. For regional autonomy without central power sharing, however, the picture is less clear-cut. In this case, the distribution straddles zero, with a considerable share of the mass above zero. This result suggests that, on average, ethnic decentralization is likely to be too little, too late for peace building, unless combined with full inclusion. More generally, we find that power sharing provisions exhibit substantially large effects in postwar situations, although these are associated with higher degrees of uncertainty. ${ }^{9}$ Thus, contrary to the autonomy skeptics' claims, we find that such provisions-especially central inclusion-are crucial in conflict-ridden situations.

Before considering the robustness of our results, we take one step beyond the mostly static comparisons conducted up to this point. As argued by McGarry and O'Leary $(2009,11)$, many critics of decentralized institutions tend to blame autonomy for what is really an attempt to centralize such arrangements. In an effort to evaluate $\mathrm{H7}$, Model 4 adds variables measuring the

\footnotetext{
${ }^{9}$ Statistically, this follows from the positive coefficient for postwar, which shifts the linear predictor to the steeper regions of the nonlinear logit link function, thus resulting in larger marginal effects.
} 


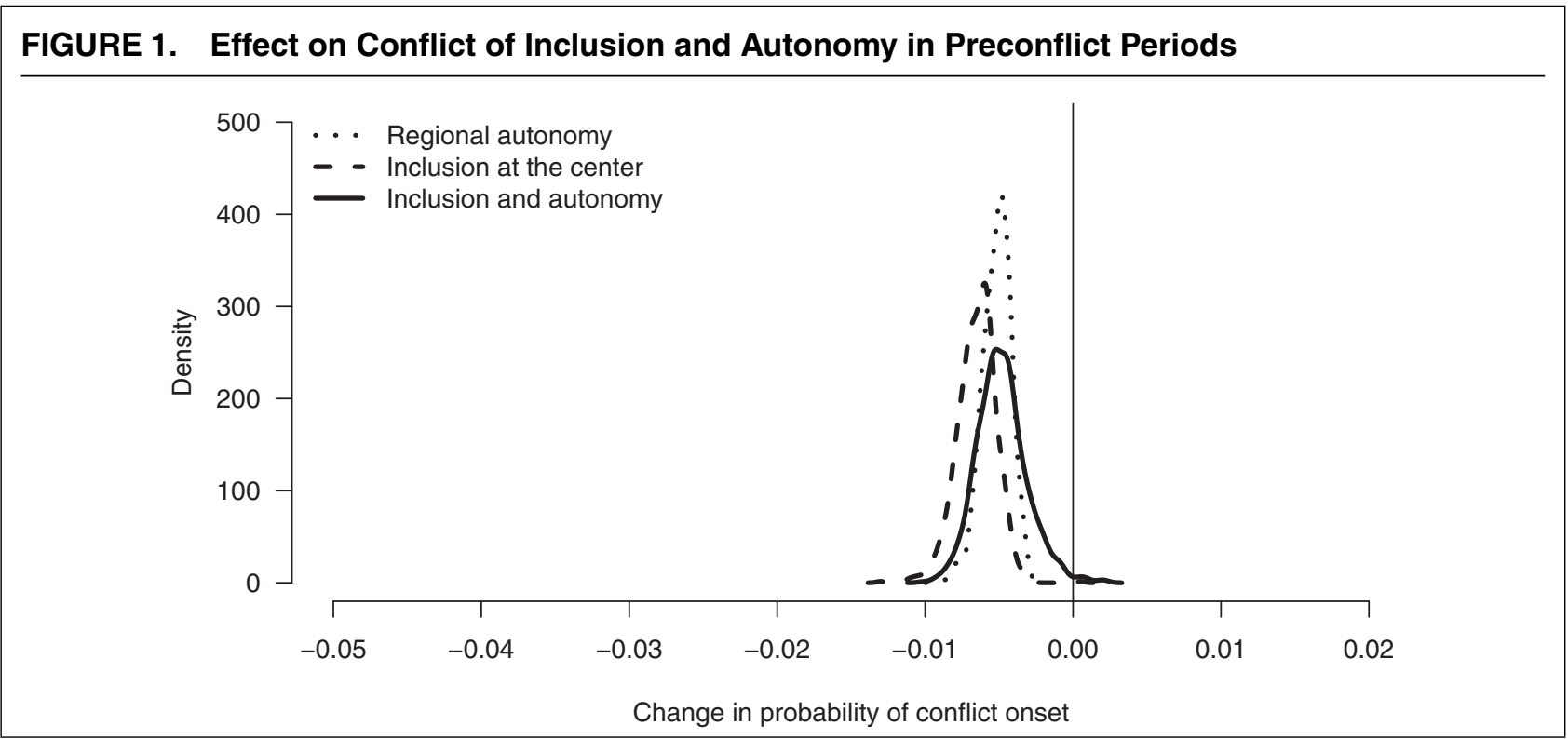

\section{FIGURE 2. Effect on Conflict of Inclusion and Autonomy in Postconflict Periods}

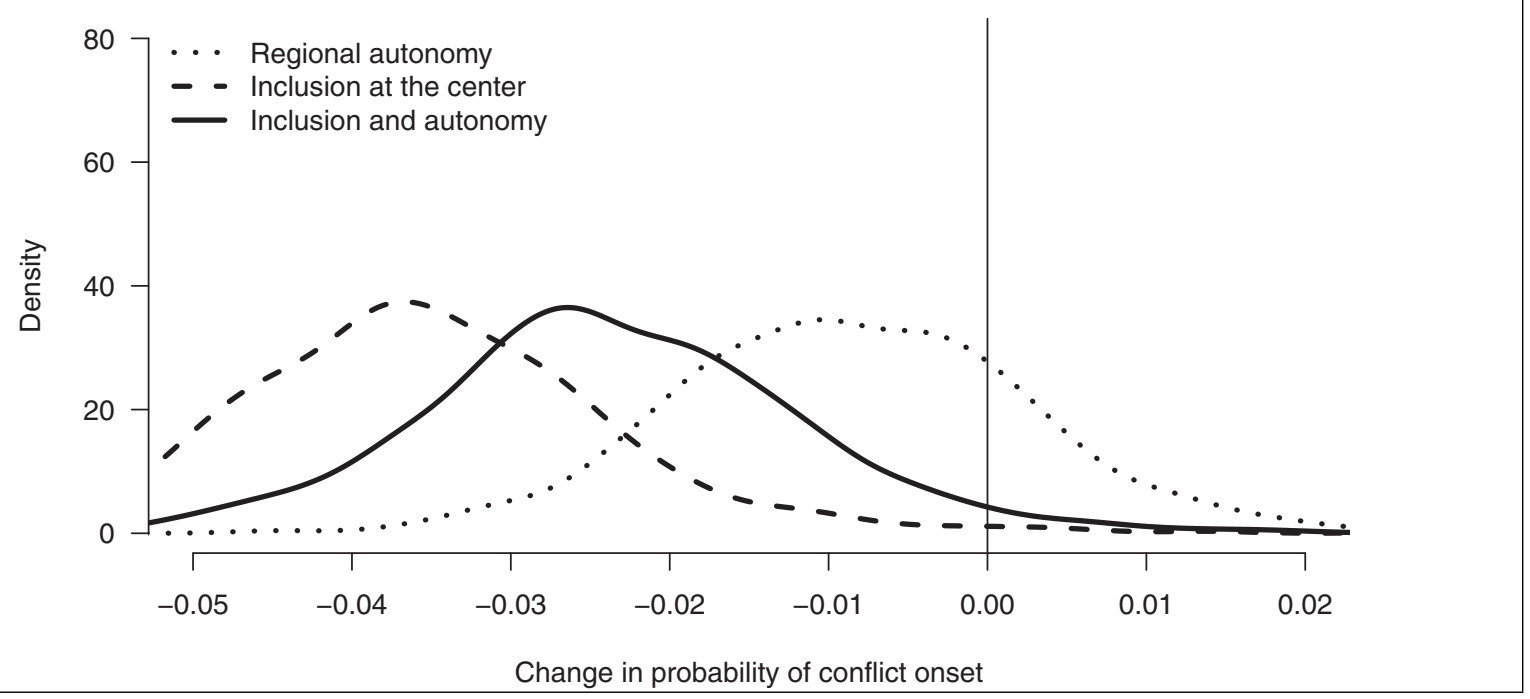

revocation of autonomy and other types of downgrading. The results indicate that those groups that experienced downgrading from autonomy within the previous two years are considerably more likely to rebel. For other types of status loss, however, there is merely a weak positive effect that cannot be safely separated from zero.

In sum, the findings of this section show that while regional autonomy appears to reduce the risk of firsttime onsets, preventing recurrent conflict hinges on full inclusion through governmental power sharing. Once autonomy is in place, however, centralization can be counterproductive since it increases the risk of recurrent violence, at least in the short run. We refer the reader to a series of sensitivity checks in the Online Appendix. Yet, one major concern remains, namely endogeneity, which is the topic of the next section.

\section{ACCOUNTING FOR ENDOGENEITY}

Up to this point, we have assumed ethnic groups' access to power to be exogenous. This assumption is potentially problematic if governments' decisions to offer groups concessions through either type of power sharing are made in anticipation of future conflict. In other words, our main explanatory variables are not randomly assigned and could therefore be at least partially dependent on a given group's conflict propensity (see Fearon, Kasara, and Laitin 2007, 193). This type of bias could lead to either an underestimation or an overestimation of the causal effect of power-sharing institutions. If opportunistic governments attempt to prevent anticipated conflict by appeasing potential "troublemakers" through self-determination, the conflict-dampening effect of inclusion will be underestimated. Such a pragmatic approach is invoked by 
representatives of dominant ethnic groups who prefer to keep as much of the state's resources as possible, while at the same time making concessions in the name of interethnic peace.

The opposite applies in situations where the government tries to preempt anticipated conflict by excluding, rather than including, threatening groups. Such precautionary measures could be implemented in order to prevent ethnic competitors from wielding influence from within governmental institutions. Applying this argument to Sub-Saharan Africa, Roessler (2011, 313) suggests that "ethnic exclusion serves as an expedient mechanism to eradicate perceived enemies." As opposed to the previous scenario, this logic would imply that the pacifying influence of both territorial and governmental power sharing may have been overestimated.

The standard way of addressing this problem of endogeneity is instrumental variable estimation. This means that we have to articulate a causal pathway that directly affects regional autonomy but is otherwise unrelated to conflict risk. There can be no doubt about the difficulty of fulfilling the criteria given by the exclusion restriction. ${ }^{10}$

Although a definitive answer to questions relating to endogenous institutions would require a more sophisticated research design than can be provided by this article, we propose an instrument that alleviates some of these concerns. An effective instrument needs to vary across groups, since much of the variation in regional autonomy is among groups and not among countries. Our starting point is Sambanis and Milanovic's (2014) straightforward observation that only sufficiently large groups can credibly demand, and expect to be granted, autonomy. However, large groups are also more likely to experience conflict because their size facilitates mobilization. Thus, group size alone cannot serve as an instrument as it affects not only autonomy demands (Sambanis and Milanovic 2014, 1838) but also conflict propensity (Cederman, Wimmer, and Min 2010, 96).

As a way forward, we instead exploit systematic differences in governance between former French and British colonies resulting from their respective colonial heritage (Blanton, Mason, and Athow 2001; Horowitz 1985; Young 1994). ${ }^{11}$ Mirroring the centralistic system of France, the French approach to colonial governance relied on a high degree of centralization (Le Vine 2004; Strang 1994). In contrast, the British adopted a much more pragmatic attitude that frequently included the use of "indirect rule," which explains why decentralization along ethnic lines remains a common response to ethnic diversity in countries with a British colonial

\footnotetext{
${ }^{10}$ Evaluating extant work, Sambanis and Milanovic (forthcoming, 9) argue that "no prior study of the effects of decentralization...has proposed a valid instrumental variables approach to estimate the causal effect of (expected or actual) conflict on decentralization or vice versa."

11 Our approach draws on Wucherpfennig, Hunziker, and Cederman (2015) who use a similar identification strategy to endogenize ethnic inclusion.
}

past. ${ }^{12}$ Consequently, in former British colonies larger groups should be more likely to enjoy regional autonomy than similar groups in former French colonies. Thus, the interaction between group size and the identity of the colonial empire constitutes an instrument that is unlikely to have an effect on conflict except through autonomy.

Our approach finds support in the literature on colonial powers. Calori et al. (1997, 691) note that the British, primarily interested in defending and expanding their commercial interests, "relied heavily on local self-government and indirect rule when controlling their colonial empire." The French, by contrast, "centralised decisions concerning their colonies, implemented actions by means of decrees and edicts, attempted to control local affairs by placing their own in local positions of power, in such the same manner as Louis XIV did with his use of 'intendents' and Napoléon did with his use of 'préfets'." Whereas the French encouraged local elites to assimilate to French culture, the British retained and empowered local chiefs by giving them far-reaching autonomy including the authority to collect taxes (Crowder 1968; Lange 2004).

These differences in the style of governance shaped the institutional characteristics of former colonies in systematic ways, as emphasized by O'Leary $(2001,280)$ :

Multinational federalists have been influential in the development of federations in the former British empire, notably in Canada, the Caribbean, Nigeria, South Africa, India, Pakistan and Malaysia.

By contrast, autonomous arrangements are particularly rare in states that experienced French colonial rule (Le Vine 2004; Strang 1994).

Consequently we expect territorial autonomy to be more likely for populous groups in former British colonies. In former French colonies, however, population size should not increase the likelihood of gaining regional autonomy. In other words, the French inclination for centralization can be expected to disadvantage those groups for which regional autonomy is otherwise most feasible. However, this does not affect small groups for which autonomy is not feasible to begin with. This logic creates systematic and increasing differences between groups in former French and British colonies depending on their size.

We exploit this difference by constructing our instrument as the interaction between the indicator for British colonial past and the absolute demographic size of the group. As opposed to using group size on its own, or colonial heritage itself, this combined variable is not related to conflict in any obvious way, except through the autonomy mechanism. ${ }^{13}$

\footnotetext{
12 Obviously, this difference between the two colonial empires concerns the general governance tradition. In terms of implementation there was considerable variation within the empires themselves and even within specific colonies (Herbst 2000; Lange 2004).

${ }^{13}$ In the Online Appendix we discuss possible challenges to our identification strategy and explain why they are not likely to undermine it.
} 


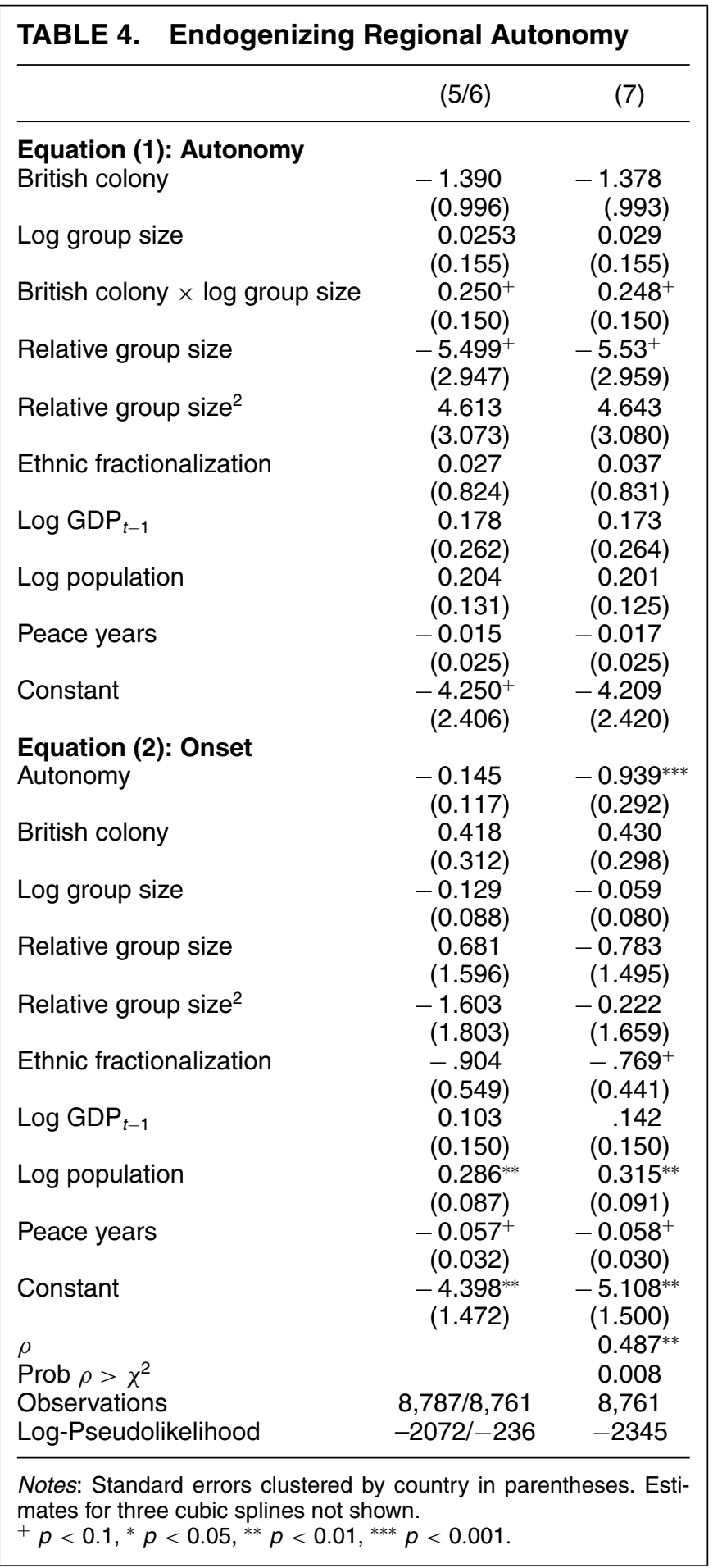

Relying on this identification strategy, we examine a sample comprised of all territorially distinctive ethnic groups in postcolonial states descending from either French or British colonial heritage. ${ }^{14}$ The approach is far from ideal because our exogenous mechanism articulated above applies only to a smaller sample. This in

\footnotetext{
${ }^{14}$ We drop European settler colonies from the sample (e.g., South
} Africa and Zimbabwe). turn forces us to assume away the important distinction between prewar and postwar effects that we analyzed in the first part of this study (although see the Online Appendix for details). Yet, these simplifications seem reasonable in view of our main goal being primarily to assess the general direction of a possible endogeneity bias as regards autonomous institutions.

Table 4 introduces the results of Models 5, 6, and 7, with the estimates of the first two models stacked on top 


\section{FIGURE 3. Effect of Autonomy on Conflict Based on Naive and Instrumented Analysis (Models 5} and 6)

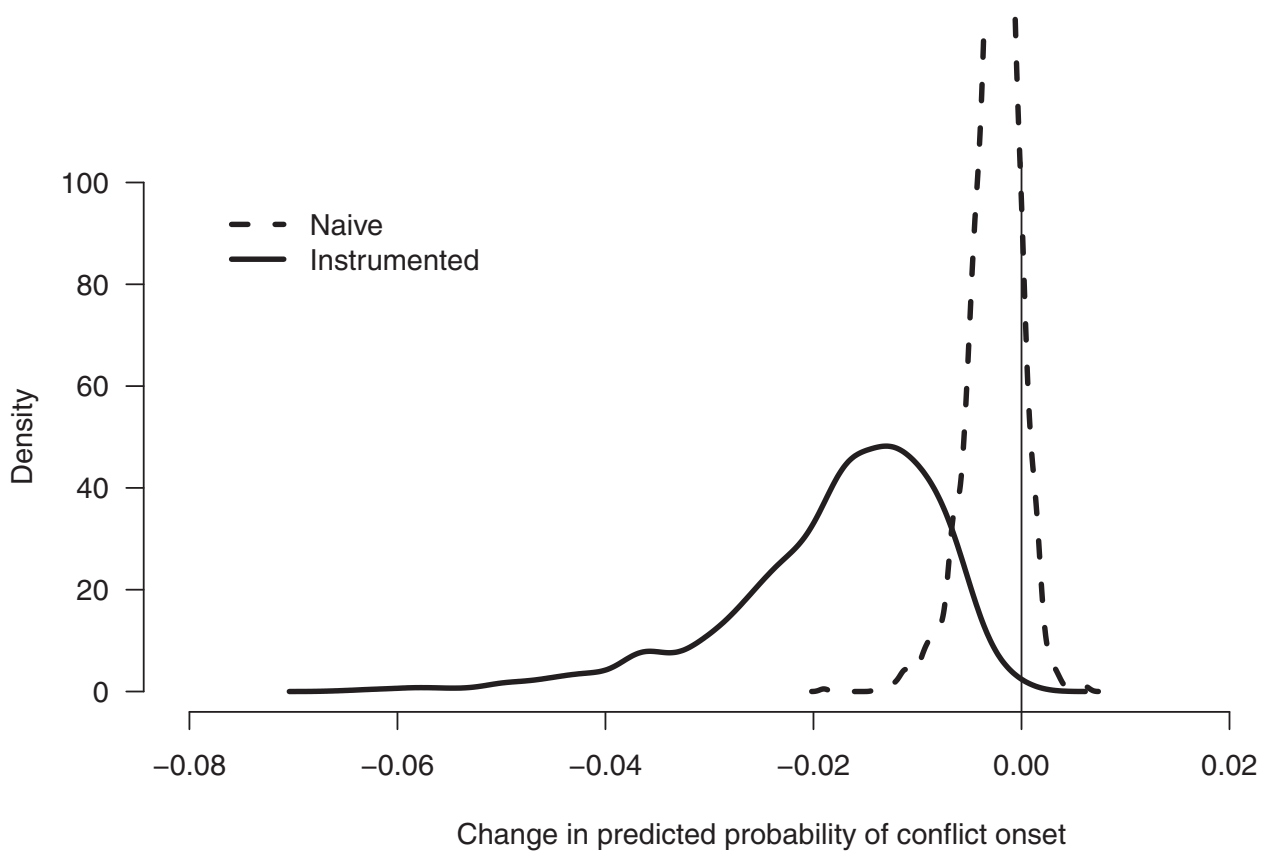

of each other in the first column. For comparative purposes, Models 5 and 6 offer naïve estimates, based on two distinct probit models that explain autonomy and conflict onset separately. Relaxing the assumption of exogenous autonomy concessions, Model 7 introduces a bivariate probit model that instruments for regional autonomy, thus yielding unbiased estimates (Maddala 1983). The model specification is very similar to the models in Table 3, with the main difference being that we drop as many of the potentially endogenous variables as possible, including the postwar variable and its interactions with the power status variables. The variables measuring ongoing conflict and the downgrading variables are also removed. Furthermore, we replace the variable measuring the number of excluded groups with an ethnodemographic measure of fractionalization based on the EPR-ETH dataset. The first equation, depicted in the upper part of the table, models the conditions under which governments grant autonomy by including the colonial dummy variable, the group's logged absolute population size, as well as the combination of both, the latter serving as the actual instrument for autonomy. The second equation in the lower part accounts for conflict onset using the same list of variables as in the first equation except for the instrument, while including our measure of regional autonomy.

The findings of Model 7 offer strong support for the opportunistic interpretation of governments' approach to ethnic diversity. Compared to the naïve analysis in Model 6, which detects a modest negative effect of autonomy on conflict, the impact is much stronger and clearly significant in the models that address reverse causation. We note that the instrument reaches conventional significance at the level of $p=0.1$. Relying on the same counterfactual method as in the previous graphs of this article, Figure 3 plots the predicted effect of autonomy on conflict for the naïve analysis of Model 6 (dashed line) and the instrumented one of Model 7 (solid line). The former density distribution (capped at 100 for easier viewing) indicates that in the uncorrected analysis, autonomous arrangements have a weakly negative influence that is hardly distinguishable from zero. Once reverse causation is taken into account in Model 7 , however, the distribution shifts left into the clearly conflict-dampening domain of the graph. ${ }^{15}$

Provided that these results are representative of the global sample of groups, we conclude that our analysis in the previous section has tended to underestimate the actual pacifying effect of territorial decentralization. Much does speak for the sample being representative, since French and British ex-colonies feature a large number of diverse countries including many important conflict cases. Furthermore, our endogeneity analysis can be seen as a tough test since it covers Sub-Saharan Africa, which is the region where the opposite tendency should apply according to Roessler (2011).

In sum, this section offers a systematic if somewhat incomplete confirmation that territorial power sharing is most likely to be invoked in cases where the conflict potential is high, as argued by McGarry and O'Leary (2009) and Grigoryan (2012). Indeed, the evidence suggests that these scholars are right, thus implying

\footnotetext{
15 To assess whether the effect of regional autonomy differs between prewar and postwar settings, we estimate the models in Table 4 for subsets of cases with and without prior conflict. The results are encouraging, although the small sample size makes estimation difficult in the postconflict subsample (see the Online Appendix).
} 
that our quantitative analysis of autonomy's pacifying influence is erring on the safe side.

\section{CONCLUSION}

Focusing on regional autonomy arrangements, we have investigated to what extent, and in what form, ethnic inclusion mitigates territorial civil war. Our point of departure has been past research indicating that exclusion of ethnic groups triggers internal conflict. However, such results do not automatically imply that regional inclusiveness will guarantee peace, especially if the relationship between an excluded group and the incumbent government has already seen violence. In such situations, we have found that, on its own, regional autonomy is likely to be "too little, too late." It is too little because only full inclusion through power sharing at the central level reduces conflict propensity significantly; and it is too late since regional autonomy could be effective, but only if offered in a timely, preventive fashion before group-government relations turn violent.

Although these findings fall short of an across-board endorsement of regional autonomy as a conflict resolution tool, they differ significantly from studies that depict ethnic decentralization, and especially ethnofederalism, as inherently pernicious and destabilizing, typically arguing in favor of partition or even ethnic dominance. Here, we have presented a disaggregated and more balanced framework that produces more encouraging results. First, we find that regional autonomy can serve a useful conflict-preventing purpose that keeps a group-government relationship peaceful, a role that the critics often overlook. Second, in stark contrast to the critics' admonitions, there is no support for a clearly conflict-fueling influence of regional autonomy even in postconflict situations. Third, our analysis indicates that ethnic inclusion at the center can effectively pacify previously violent relationships. Thus, if regional autonomy is to be offered, it should be combined with power sharing within the national executive as recommended by McGarry and O'Leary (2009). Fourth, and finally, our efforts to take the endogeneity of autonomy concessions into account in postcolonial settings indicates that governments typically offer such accommodation in order to dissuade threatening groups from resorting to violence, which in turn implies that we have been erring on the safe side with our causal inferences. If anything, the actual pacifying effect of decentralization is likely to be even more powerful than uncorrected analysis suggests.

These are important empirical results that directly contradict claims that no solution short of partition can possibly improve the situation (e.g., Chapman and Roeder 2007; Kaufmann 1996). In addition to individual rights, regional autonomy offers an appealing alternative to groups' remedial right to secede since its geopolitical effects are considerably less destabilizing (Buchanan 2004). In sum, our main results uphold the intuitive and normatively attractive principle according to which ethnic inclusion produces peace.
While we believe to have disentangled some important aspects of power sharing with this study, this is obviously far from the final word on the matter. At least two important areas of further research stand out. First, much more can be said about the types of territorial and governmental power sharing offered by governments. In particular, it would be useful to differentiate between different dimensions of power sharing, including military and economic types, from the postconflict literature to all cases. Moreover, we expect that the shape of governance units and the extent to which they coincide with ethnic settlement areas could have a major influence on the conflict propensity of regional autonomy. Specific policies, including fiscal transfers addressing inequality, are also likely to influence the risk of conflict (Bakke and Wibbels 2006).

Second, and most importantly, the main challenge will be to address the issue of endogeneity more squarely than has been possible in this study. While we have been able to develop an instrument for regional autonomy for an important subset of cases, which suggests that our analysis is extremely unlikely to overestimate the effect of such inclusive arrangement, more work needs to be done to support the case for decentralization as a method of conflict resolution. Future research will have to offer a clearer picture of the conditions under which governments decide to grant different types of ethnic inclusion to previously excluded groups, and integrate these findings in sophisticated research designs that take the possibility of reverse causation into account in a more nuanced way. Such analysis will require more fine-grained data on sequences of claims and concessions (Sambanis and Zinn 2006) and will need to consider the strategic interaction among peripheral groups explicitly (Lacina 2013; Walter 2009).

For now, we conclude that our evidence suggests that much of previous research has underestimated the effectiveness of territorial power sharing. But this is not a blanket endorsement of decentralization schemes. Although autonomous institutions can be helpful as a supplement, the main road to peace in ethnically divided societies runs through full inclusion at the center via power sharing, especially after the eruption of large-scale political violence.

\section{REFERENCES}

Asal, Victor, Mitchell Brown, and Angela Dalton. 2012. "Why Split? Organizational Splits among Ethnopolitical Organizations in the Middle East." Journal of Conflict Resolution 56 (1): 94-117.

Bah, Abu Bakarr. 2005. Breakdowns and Reconstitution: Democracy, the Nation-state, and Ethnicity in Nigeria. Lanham, MD: Lexington Books.

Bakke, Kristin M. 2015. Decentralization and Intrastate Struggles: Chechnya, Punjab, and Quebec. New York: Cambridge University Press.

Bakke, Kristin M., and Erik Wibbels. 2006. "Diversity, Disparity, and Civil Conflict in Federal States." World Politics 59: 1-50.

Bar-Tal, Daniel. 2013. Intractable Conflicts: Socio-Psychological Foundations and Dynamics. Cambridge: Cambridge University Press.

Beck, Nathaniel, Jonathan Katz, and Richard Tucker. 1998. "Taking Time Seriously: Time-Series-Cross-Section Analysis with a Binary 
Dependent Variable." American Journal of Political Science 42 (4): 1260-88.

Bednar, Jenna. 2008. The Robust Federation. New York: Cambridge University Press.

Bertrand, Jacques. 2000. "Peace and Conflict in the Southern Philippines: Why the 1996 Peace Agreement is Fragile." Pacific Affairs 73 (1): 37-54.

Blanton, Robert, T. David Mason, and Brian Athow. 2001. "Colonial Style and Post-Colonial Ethnic Conflict in Africa." Journal of Peace Research 38 (4): 473-91.

Blattman, Christopher, and Edward Miguel. 2010. "Civil War.” Journal of Economic Literature 48 (1): 3-57.

Brancati, Dawn. 2006. "Decentralization: Fueling the Fire or Dampening the Flames of Ethnic Conflict and Secessionism." International Organization 60 (3): 651-85.

Brubaker, Rogers. 1996. Nationalism Reframed: Nationhood and the National Question in the New Europe. Cambridge: Cambridge University Press.

Buchanan, Allen. 2004. Justice, Legitimacy, and Self-Determination: Moral Foundations for International Law. Oxford: Oxford University Press.

Bunce, Valerie. 1999. Subversive Institutions: The Design and the Destruction of Socialism and the State. Cambridge: Cambridge University Press.

Bunce, Valerie, and Stephen Watts. 2005. "Managing Diversity and Sustaining Democracy: Ethnofederal versus Unitary States in the Postcommunist World." In Sustainable Peace: Power and Democracy After Civil Wars. Ithaca: Cornell University Press, 133-58.

Calori, Roland, Michael Lubatkin, Philippe Very, and John F. Veiga. 1997. "Modelling the Origins of Nationally-Bound Adminstrative Heritages: A Historical Institutional Analysis of French and British Firms." Organizational Science 8 (6): 681-96.

Cederman, Lars-Erik. 2013. "Nationalism and Ethnicity." In Handbook of International Relations, 2nd ed., ed. Walter Carlsnaes, Thomas Risse, and Beth Simmons. London: Sage.

Cederman, Lars-Erik, and Luc Girardin. 2007. "Beyond Fractionalization: Mapping Ethnicity onto Nationalist Insurgencies." American Political Science Review 101 (1): 173-85.

Cederman, Lars-Erik, Kristian Skrede Gleditsch, and Halvard Buhaug. 2013. Inequality, Grievances and Civil War. New York: Cambridge University Press.

Cederman, Lars-Erik, Nils B. Weidmann, and Kristian Skrede Gleditsch. 2011. "Horizontal Inequalities and Ethno-Nationalist Civil War: A Global Comparison." American Political Science Review 105 (3): 478-95.

Cederman, Lars-Erik, Andreas Wimmer, and Brian Min. 2010. "Why Do Ethnic-Nationalist Groups Rebel: New Data and Analysis." World Politics 62 (1): 87-119.

Chapman, Thomas, and Philip G. Roeder. 2007. "Partition as a Solution to Wars of Nationalism: The Importance of Institutions." American Political Science Review 101 (4): 677-91.

Christin, Thomas, and Simon Hug. 2012. "Federalism, the Geographic Location of Groups, and Conflict." Conflict Management and Peace Science 29 (1): 92-121.

Collier, Paul, and Nicholas Sambanis. 2002. "Understanding Civil War: A New Agenda." Journal of Conflict Resolution 46 (1): 3-12.

Cornell, Svante E. 2002. "Autonomy as a Source of Conflict. Caucasian Conflicts in Theoretical Perspective." World Politics 54 (2): 245-76.

Crowder, Michael. 1968. West Africa under Colonial Rule. London: Hutchinson.

Cunningham, Kathleen Gallagher. 2011. "Divide and Conquer or Divide and Concede: How Do States Respond to Internally Divided Separatists?" American Political Science Review 105: 275-97.

Cunningham, David E., Kristian S. Gleditsch, and Idean Salehyan. 2009. "It Takes Two: A Dyadic Analysis of Civil War Duration and Outcome." Journal of Conflict Resolution 53 (4): 570-97.

Elbadawi, Ibrahim, Håvard Hegre, and Gary J. Milante. 2008. "The Aftermath of Civil War. "Journal of Peace Research 45 (4): 451-9.

Elkins, Zachary, and John Sides. 2007. "Can Institutions Build Unity in Multiethnic States?" American Political Science Review 101 (4): 693-708.

Fearon, James D., Kimuli Kasara, and David D. Laitin. 2007. "Ethnic Minority Rule and Civil War Onset." American Political Science Review 101 (1): 187-93.
Filippov, Mikhail, Peter Ordeshook, and Olga Shvetsova. 2004. Designing Federalism: A Theory of Self-Sustainable Federal Institutions. Cambridge: Cambridge University Press.

Fleshman, Michael. 2001. "Small Arms in Africa: Continuing the Cost of Gun Violence." Africa Recovery 15 (4): 14-21.

Gagnon, V. P. Jr. 2004. The Myth of Ethnic War: Serbia and Croatia in the 1990s. Ithaca, NY: Cornell University Press.

Gellner, Ernest. 1983. Nations and Nationalism. Ithaca, NY: Cornell University Press.

Gelman, Andrew, and Jennifer Hill. 2007. Data Analysis Using Regression and Multilevel/Hierarchical Models. New York: Cambridge University Press.

Ghai, Yash P. 2000. "Ethnicity and Autonomy: A Framework for Analysis." In Autonomy and Ethnicity : Negotiating Competing Claims in Multi-EthnicStates, ed. Yash P. Ghai. Cambridge: Cambridge University Press, 1-26.

Glassmyer, Katherine, and Nicholas Sambanis. 2008. "Rebel-military Integration and Civil War Termination." Journal of Peace Research 45 (3): 365-84.

Gleditsch, Nils Petter, Peter Wallensteen, Mikael Eriksson, Margareta Sollenberg, and Håvard Strand. 2002. "Armed Conflict 1946-2001: A New Dataset." Journal of Peace Research 39 (5): 615-37.

Grigoryan, Arman. 2012. "Ethnofederalism, Separatism, and Conflict: What We Have Learned From the Soviet and Yugoslav Experiences." International Political Science Review 33 (5): 520-38.

Guha, Ramachandra. 2008. India After Gandhi: The History of the World's Largest Democracy. London: Pan Macmillan.

Gurr, Ted Robert. 1993. Minorities at Risk. A Global View of Ethnopolitical Conflict. Washington: United States Institute of Peace Press.

Gurr, Ted Robert. 2000a. "Ethnic Warfare on the Wane." Foreign Affairs 79 (3): 52-65.

Gurr, Ted Robert. 2000b. Peoples Versus States: Minorities at Risk in the New Century. Washington, DC: US Institute of Peace.

Hale, Henry E. 2008. The Foundations of Ethnic Politics: Separatism of States and Nations in Eurasia and the World. New York: Cambridge University Press.

Hannum, Hurst. 1996. Autonomy, Sovereignty, and SelfDetermination: The Accommodation of Conflict Rights, rev. ed. Philadelphia: University of Pennsylvania Press.

Hartzell, Caroline, and Matthew Hoddie. 2003. "Institutionalizing Peace: Power Sharing and Post-civil Conflict Management." American Journal of Political Science 47 (2): 318-32.

Hartzell, Caroline, Matthew Hoddie, and Donald Rothchild. 2001. "Stabilizing the Peace After Civil War: An Investigation of Some Key Variables." International Organization 55 (1): 183 208.

Hechter, Michael. 2000. Containing Nationalism. Oxford: Oxford University Press.

Hechter, Michael. 2004. "Containing Ethnonationalist Violence.” In Facing Ethnic Conlicts: Toward a New Realism, eds. Andreas Wimmer, Richard J. Goldstone, Donald L. Horowitz, Ulrike Joras, and Conrad Schetter. Lanham, MD: Rowman and Littlefield.

Herbst, Jeffrey. 2000. States and Power in Africa: Comparative Lessons in Authority and Control. Princeton: Princeton University Press.

Heston, Alan, Robert Summers, and Bettina Aten. 2011. "Penn World Table Version 7.0." Center for International Comparisons of Production, Income and Prices at the University of Pennsylvania.

Hoddie, Matthew, and Caroline Hartzell. 2005. "Power Sharing in Peace Settlements: Initiating the Transition from Civil War." In Sustainable Peace: Power and Democracy After Civil Wars, eds. Philip G. Roeder and Donald Rothchild. Ithaca: Cornell University Press, 83-106.

Horowitz, Donald. 1985. Ethnic Groups in Conflict. Berkeley: University of California Press.

Hug, Simon. 2013. "The Use and Misuse of the 'Minorities at Risk' Project." Annual Review of Political Science 16: 191-208.

Jarstad, Anna, and Desirée Nilsson. 2008. "From Words to Deeds: The implementation of Power-Sharing Pacts in Peace Accords." Conflict Management and Peace Science 25: 208-23.

Kalyvas, Stathis. 2006. From The Logic of Violence in Civil War. New York: Cambridge University Press. 
Kaufmann, Chaim. 1996. "Possible and Impossible Solutions to Ethnic Conflict." International Security 20 (4): 136-75.

Kymlicka, W. 1998. "Is Federalism a Viable Alternative to Secession?" In Theories of Secession, ed. Percy Lehning. London: Routledge, 111-50.

Lacina, Bethany. 2009. "The Problem of Political Stability in Northeast India: Local Ethnic Autocracy and the Rule of Law." Asian Survey 49 (6): 998-1020.

Lacina, Bethany. 2015. "Periphery versus Periphery: The Stakes of Separatist War." Journal of Politics.

Lake, David A., and Donald Rothchild. 2005. "Territorial Decentralization and Civil War Settlements." In Sustainable Peace: Power and Democracy After Civil Wars, eds. Philip G. Roeder and Donald Rothchild. Ithaca, NY: Cornell University Press, 109-32.

Lange, Matthew K. 2004. "British Colonial Legacies and Political Development." World Development 32 (6): 905-22.

Langer, Armin, and Frances Stewart. 2013. "Horizontal Inequalities and Violent Conflict: Conceptual and Empirical Linkages." Working Paper No. 14, Center for Research on Peace and Development, Leuven.

Le Vine, Victor T. 2004. Politics in Francophone Africa. Boulder: Lynne Rienner.

Lijphart, Arend. 1969. "Consociational Democracy." World Politics 21 (2): 207-25.

Lijphart, Arend.1975. The Politics of Accommodation: Pluralism and Democracy in the Netherlands. Berkeley: University of California Press.

Lijphart, Arend. 1985. "Non-Majoritarian Democracy: A Comparison of Federal and Consociational Theories." Publius: The Journal of Federalism 15 (2): 3-15.

Lustick, Ian S., Dan Miodownik, and Roy J. Eidelson. 2004. "Secessionism in Multicultural States: Does Sharing Power Prevent or Encourage It?" American Political Science Review 98 (2): 209-29.

Maddala, Gangadharrao Soundarlyarao. 1983. Limited Dependent and Qualitative Variables. Cambridge: Cambridge University Press.

Martin, Philipp. 2013. "Coming Together: Power-Sharing and the Durability of Negotiated Peace Settlements." Civil Wars 15 (3): $332-58$.

Mattes, Michaela, and Burcu Savun. 2009. "Fostering Peace After Civil War: Commitment Problems and Agreement Design." International Studies Quarterly 53: 737-59.

McGarry, John, and Brendan O'Leary. 2005. "Federation as a Method of Ethnic Conflict Regulation." In From Power Sharing to Democracy, ed. Sid Noel. Montreal: McGill-Queen's University Press, 263-96.

McGarry, John, and Brendan O'Leary. 2009. "Must Pluri-national Federations Fail?" Ethnopolitics 8 (1): 5-25.

Negash, Tekeste. 1997. Eritrea and Ethiopia: The Federal Experience. New Brunswick: Transaction Publishers.

O'Leary, Brendan. 2001. "An Iron Law of Nationalism and Federation?: A (Neo-Diceyian) Theory of the Necessity of a Federal Staatsvolk, and of Consociational Rescue." Nations and Nationalism 7 (3): 273-96.

O'Leary, Brendan. 2012. "The Federalization of Iraq and the Breakup of Sudan." Government and Opposition 47 (4): 481-516.

Petersen, Roger D. 2002. Understanding Ethnic Violence: Fear, Hatred, and Resentment in Twentieth Century Eastern Europe. Cambridge: Cambridge University Press.

Quinn, J. Michael, T. David Mason, and Mehmet Gurses. 2007. "Sustaining the Peace: Determinants of Civil War Recurrence." International Interactions 33 (2): 167-93.

Rabushka, Alvin, and Kenneth A. Shepsle. 1972. Politics in Plural Societies: A Theory of Democratic Instability. Columbus: C.E. Merrill.

Riker, William H. 1964. Federalism: Origin, Operation, Significance. Boston: Little, Brown.
Roeder, Philip G. 2007. Where Nation-States Come From. Princeton: Princeton University Press.

Roeder, Philip G., and Donald Rothchild, eds. 2005. Sustainable Peace: Power and Democracy After Civil Wars. Ithaca, NY: Cornell University Press.

Roessler, Philip. 2011. "The Enemy Within: Personal Rule, Coups and Civil War in Africa." World Politics 63 (2): 300-46.

Rothchild, Donald. 2008. "Africa's Power Sharing Institutions as a Response to Insecurity." In Intra-State Conflict, Governments and Security: Dilemmas of Deterrence and Assurance, eds. Stephen M. Saideman and Marie-Joëlle Zahar. London: Routledge, 138-60.

Rothchild, Donald, and Philip G. Roeder. 2005. "Dilemmas of State-Building in Divided Societies." In Sustainable Peace: Power and Democracy After Civil Wars, eds. Philip G. Roeder and Donald Rothchild. Ithaca, NY: Cornell University Press, 1-25.

Rydgren, Jens. 2007. "The Power of the Past: A Contribution to a Cognitive Sociology of Ethnic Conflict." Sociological Theory 25 (3): 225-44.

Sambanis, Nicholas, and Branko Milanovic. 2014. "Explaining Regional Autonomy Differences in Decentralized Countries." Comparative Political Studies 47 (13): 1830-55.

Sambanis, Nicholas, and Annalisa Zinn. 2006. "From Protest to Violence: Conflict Escalation in Self-Determination Movements." Unpublished paper, Yale University.

Samii, Cyrus. 2013. "Who Wants to Forgive and Forget? Transitional Justice Preferences in Postwar Burundi." Journal of Peace Research 50 (2): 219-33.

Singh, Gurharpal. 1993. "Ethnic Conflict in India: A Case-Study of Punjab." In The Politics of Ethnic Conflict Regulation: Case Studies of Protracted Ethnic Conflicts, eds. John McGarry, and Brendan O'Leary. Baltimore: Routledge, Chap. 4, 84-105.

Snyder, Jack. 2000. From Voting to Violence: Democratization and Nationalist Conflict. New York: Norton.

Strang, David. 1994. "British and French Political Institutions and the Patterning of Decolonization." In The Comparative Political Economy of the Welfare State, eds. Thomas Janoski, and Alexander M. Hicks. Cambridge: Cambridge University Press, 278-95.

Tiebout, Charles M. 1957. "A Pure Theory of Local Expenditures." Journal of Political Economy 64: 416-24.

Walter, Barbara F. 2002. Commiting to Peace: The Successful Settlement of Civil Wars. Princeton: Princeton University Press.

Walter, Barbara F. 2004. "Does Conflict Beget Conflict? Explaining Recurring Civil War." Journal of Peace Research 41 (3): 371-88.

Walter, Barbara F. 2009. Reputation and Civil War: Why Separatist Conflicts Are So Violent. Cambridge: Cambridge University Press.

Wood, Elisabeth Jean. 2008. "The Social Processes of Civil War: The Wartime Transformation of Social Networks." Annual Review of Political Science 11: 539-61.

Wucherpfennig, Julian, Philipp M. Hunziker, and Lars-Erik Cederman. 2015. "Who Inherits the State? Colonial Rule and PostColonial Conflict." Working Paper. University College London and ETH Zurich.

Wucherpfennig, Julian, Nils Metternich, Lars-Erik Cederman, and Kristian S. Gleditsch. 2012. "Ethnicity, the State, and the Duration of Civil Wars." World Politics 64: 79-115.

Wucherpfennig, Julian, Nils B. Weidmann, Luc Girardin, Lars-Erik Cederman, and Andreas Wimmer. 2011. "Politically Relevant Ethnic Groups across Space and Time: Introducing the GeoEPR Dataset." Conflict Management and Peace Science 28 (5): 423-37.

Young, Crawford. 1994. The African Colonial State in Comparative Perspective. New Haven: Yale University Press.

Young, John. 2006. Peasant Revolution in Ethiopia: The Tigray People's Liberation Front, 1975-1991. New York: Cambridge University Press. 